\title{
Disabled People's Vulnerability in the European Single Market: The Case of Consumer Information
}

\section{Eskyte ${ }^{1}$}

Received: 30 December 2018 / Accepted: 28 June 2019 / Published online: 19 July 2019

(C) The Author(s) 2019

\begin{abstract}
The United Nations Convention on the Rights of Persons with Disabilities (2006) recognizes access to consumer goods and services in the mainstream private market as essential for full participation in the society. It shapes the concepts of consumer participation and market accessibility around the social model of disability and does not make a distinction between disabled and non-disabled market participants. Meanwhile, the European Union and Member States do not recognize people with impairments as equal market participants. They see them as "vulnerable" consumers and classify impairment as one of the criteria for becoming a "vulnerable" participant in the European single market. This paper argues, however, that by shaping policy and market positions and actions around ableism, the European Union, Member States, and the private market prioritize non-disabled citizens and consumers and so construct people with impairments' consumer vulnerability. To illustrate the case, empirical evidence from mystery shopping and qualitative interviews with consumers with impairments from Lithuania and the UK is used. Since consumer information is essential for informed choice and participation in the market, information provision about mainstream retail outlets and products is used as a case study.
\end{abstract}

Keywords Disabled consumers · Accessibility · Consumer information · Vulnerability · Ableism · Accessible markets

In recent years, the increasing number of disabled people (Coleman and Lebbon 2010; European Commission 2011), their growing spending power (Eurostat 2009; Kingman 2012; Office for Disability Issues 2010), and disability movements challenged the positioning of people with impairments as passive recipients of health, rehabilitation, and social care services. The discourse of disabled people as active participants of the mainstream private market who should hold equal rights as those of non-disabled individuals has become significantly stronger. The United Nations (UN) Convention on the Rights of Persons with

I. Eskytè

i.eskyte@leeds.ac.uk

1 School of Law, Centre for Disability Studies, Centre for Law and Social Justice, University of Leeds, Leeds LS2 9JT, UK 
Disabilities (CRPD) 2006 provided the foundation for this ontological shift to be legally recognized and addressed by the State Parties. Article 9 of the Convention requires State Parties to "ensure that private entities that offer facilities and services which are open or provided for the public, take into account all aspects of accessibility for persons with disabilities" (Art. 9.2.b). Alongside the call for markets accessibility, the Treaty requires taking appropriate measures to ensure that disabled people have access, on equal basis with others, to information and communications (Art. 9.1), including consumer information. Equality is the underlying principle of the Convention and is a strong foundation behind the article 9 (Ferri 2010; Kayess and French 2008; Lawson 2010). Consequently, private entities should expect and respect the diversity of disabled consumers, and treat them on an equal basis with nondisabled market participants (Kayess and French 2008). The Convention also aims to eliminate social exclusion (Ferri 2010) and promote personal autonomy (Mégret 2008). Consequently, the intertwining of the three aspects (equality, social participation, and personal autonomy) establishes accessibility of the mainstream private market and equality of the disabled people as active market participants. State Parties who have signed and ratified the Convention are obliged to provide legal and policy frameworks, within which private actors engage in the public discourse and implement the obligations in practice.

The European Union (EU) signed and ratified the Convention on 23 December 2010. Consequently, it is committed to integrate the principles of accessibility and equal participation in the EU single market in its legislation and to ensure this right includes disabled Europeans. However, the Union does not have the competence to act solely in the interest of protecting consumers nor to ensure their rights; the impact is indirect and competence is linked to the single market objectives (Miller 2011). Nevertheless, the EU aims to promote consumers' interests and to ensure their rights and protection (TFEU 2012, Art. 169). As some of the means to achieve this goal, the Union has established fundamental principles of consumer protection, acknowledged that distortive practices within the private market do exist, and defined two groups of consumers: "average" and "vulnerable." With regard to the protection of "average" consumers, the emphasis is on market practice, which "materially distorts or is likely to materially distort the economic behaviour with regard to the product of the average consumer whom it reaches or to whom it is addressed" (European Council Unfair Commercial Practice Directive 2005). While dealing with the protection of "vulnerable" consumers group, to which people with impairments are ascribed, the Union defines them as vulnerable "to the practice or the underlying product because of their mental or physical infirmity, age or credulity" (European Council Unfair Commercial Practice Directive 2005).

Since Member States (MSs) have to incorporate regional policies into national legislations (Eskyte 2019), it is not surprising that a similar discourse is present across Europe. As an example, Lithuanian policy regulations rank people with impairments as "socially vulnerable consumers." The category is not officially established and may change according to the government or its authorized institution (Lietuvos Respublikos Seimas Elektros Istatymas 2012). Usually, single parents, under-retirement age, or unskilled young and unemployed people, ethnic minorities, and people with impairments fall under this definition (VPVI 2011). In a similar vein, the UK categorizes people with impairments as "vulnerable consumers." As in Lithuania, the primary UK legislation in the consumer area lacks focus on and reference to disabled people. The Consumer Protection from Unfair Trading Regulations (2012) makes an exception and refers to "mental or physical infirmity, age or credulity" (Part 1.2(5)):

(5) In determining the effect of a commercial practice on the average consumer- 
(a) where a clearly identifiable group of consumers is particularly vulnerable to the practice or the underlying product because of their mental or physical infirmity, age and credulity in a way which the trader could reasonably be expected to foresee.

Guidance on the UK Regulations (May 2008) implementing the Unfair Commercial Practice Directive (Office of Fair Trading 2008) reinforces such a position. The document states that "consumers are only treated as vulnerable to a practice or to the underlying product, if they are vulnerable because of infirmity, age or credulity" (14.37). Thus, as in the EU, the UK considers impairment to be one of the reasons why disabled people experience vulnerability when they engage in consumer participation.

Regional and national consumer policy regulations seem to be shaped around the individual model of disability (Eskyte 2019) that ranks impairment as a key-source of inequalities and discrimination experienced by people with impairments, and ignores the role played by external structures and factors in the disablement process (Barnes and Mercer 2003; Oliver 2004). Indeed, there is much to say against ranking impairment as one of the core reasons for individuals' vulnerability as consumers. Research, for instance, shows that in policy regulations, non-disabled consumers' competencies (Edward et al. 2000) and perceived normality standards and functions (Amundson 2005) are often used to measure consumers with impairments' vulnerability. Such policy discourse ignores universality of vulnerability (Fineman 2012) and ranks non-disabled people as a reference point for defining consumer participation, while providing people without impairments with legal superiority as private market participants (Eskyte 2019). Consequently, those who do not meet the "normality" standards are defined as "vulnerable" and left to deal individually with vulnerability experiences that are common for many. The introduction of the "average" and "vulnerable" consumer categories communicates to the public what is a "normal" and expected, and what is an "abnormal" and less expected participant of the EU single market.

Linking consumer vulnerability to who experiences vulnerability (Baker et al. 2005) leads to perceived rather than actual vulnerability (Smith and Cooper-Martin 1997) and suggests a paternalistic approach. Positioning vulnerability in direct relationship to one's dependency upon an administrative category prevents the identification of those with high risk and those who may engage in risky behaviours (Baker et al. 2016). The term is impregnated with victimization, dependency, deviation, and injustice (Eskyte 2019; Fineman 2004, 2010a, 2012; Gilson 2011) and sheds light on the individual's responsibility for his or her situation. While often gender, race, ethnicity, age, and impairments are perceived as factors causing permanent consumer vulnerability (Baker et al. 2001; Bristor et al. 1995; Fineman 2012; Hill and Dhanda 1999), "there is no empirical proof that biophysical characteristics of individuals (age, ethnicity, disability) should be the sole basis on which to define consumer vulnerability" (Baker et al. 2005, p. 130). On the other hand, vulnerability is a part of one's everyday life; it is universal and constant, inherent in the human condition (Fineman 2011). Everyone at different stages and circumstances of life can become vulnerable, often due to unpredictable material realities (e.g., harm, injury, misfortune) (Fineman 2011), natural hazards (e.g., hurricane, floods) (Hemingway and Priestley 2006; Jongman et al. 2015), climate change (e.g., air pollution, extreme weather) (Haines et al. 2006; Levy and Patz 2015; Orru et al. 2017), and other factors that people are not able to control or eliminate. These vulnerabilities are not caused by the body itself yet they disrupt an individual's institutional and social relationships. Resilience opportunities provided by different institutions play an important role in "lessening, ameliorating, and compensating for vulnerability" (Fineman, p. 269). 
Ringold (1995) suggests that individuals belonging to a certain gender, ethnic, or racial group do not determine vulnerability in the market. Representatives of these groups are equally competent consumers. On the other hand, stigmatization and categorization of those who do not meet the pre-defined market standards and deviate from what is perceived as a "normal" shopper lead to consumer vulnerability (Peñaloza 1995) and exclusion from acquisition of mainstream goods and services (Baker et al. 2005; Eskyte 2013). Fineman suggests that it is the state that legitimizes and gives status to societal organizations and institutions that provide individuals with resources for resilience. In the context of disabled consumer vulnerability in the mainstream private market, it can be argued that by defining disabled people as vulnerable consumers, the EU and MSs (1) ignore universality of vulnerability, especially in capitalist market relations, and inappropriately construct relationships of difference and distance between individuals as market participants and (2) make individuals personally responsible for their performance as customers and consequently minimize businesses' responsibility to provide all customers with resources and assets for their equal and successful participation.

In light of this literature, it seems reasonable to question the discourse and practice of regional and national policy regulations that categorize people as participants of the EU single market according to their physical and cognitive impairments and mental health conditions. Indeed, the CRPD 2006 and disability movement suggest that social, cultural, political, and market forces that are independent of individuals' impairments are the main factors causing their exclusion and vulnerability (Barnes and Mercer 1996; Barnes and Mercer 2003; Oliver 2004). While a number of studies do address people with impairments' experiences in the market, the focus is usually on consumers with mobility and vision impairments and their interaction in retail premises (Advani et al. 2017; Kaufman 1995; Kaufman-Scarborough 2001; Zientara et al. 2017). In fact, there is hardly any research that goes beyond issues such as physical barriers in public buildings, inaccessibility of indoor retail premises, or the attitude of shop assistants. For instance, what do we know about how consumer information, that is a pre-condition for consumer participation, shapes disabled people's shopping and overall experience in the market? How does providing non-disabled consumer-oriented information on where and what to purchase impact choices for people with impairments? How do people with different impairments approach the same information sources? How do the strategies chosen to communicate with potential shoppers in the high street affect the shopping of people with impairments and how do they respond to and cope with consumer information created by and for people without impairments?

We know precious little about the way current consumer information practices shape the shopping patterns of people with impairments, or their consumer participation and vulnerability. The available evidence is limited and at best, generic. For instance, some research suggests that consumer information provision in alternative formats, such as Braille, large print, audio, sign language, text-based information, and easy-to-read texts and symbols, is limited or absent (Eskyte 2019; Waddington 2009). According to other research, limited access to consumer information is a factor that eliminates disabled people from selecting items that meet their expectations and lessens the possibility to participate in the economy (Howells 2005). While work by Baker et al. (2001) provided a more detailed insight, it focused on people with vision impairments and concluded that a lack of accessible information decreases individuals' independency and causes the need for assistance in shopping, even though this group of consumers is capable of making independent purchase decisions. In addition, Eskyte (2019) provides evidence that suggests how limited provision of consumer information in alternative formats leads people with vision, hearing, or cognitive impairments to misguided shopping 
decisions, financial loss, while constraining their consumer experience. Therefore, we need a holistic approach to consumer information acquisition practices and experiences across the board of people with impairments, and to use the experiences of disabled shoppers and business players to challenge the legally established notion of consumer vulnerability.

The aim of this article is to add to the literature on the issue of this matter. To be precise, consumer information about mainstream retailers as well as goods and services is used as a case study to demonstrate that disabled people's consumer vulnerability is not a direct outcome of their impairments, but is a result of ableism and the synergy between business and the policy regulations that focus on non-disabled market participants. To this end, the paper reports an international qualitative study that focuses on an accessible shopping chain in the EU single market. As mentioned, regional and national policy regulations identify people with impairments as "vulnerable" consumers and ground their vulnerability on their impairments. However, if we assume, in line with the existing literature (Barnes and Mercer 1996, 2003, 2005; Campbell and Oliver 1996; Imrie 2013; Priestley et al. 2007; Oliver 1990, 1994, 2009), that social, cultural, historical, and capitalist market structures as well as other external factors play a key role in excluding and marginalizing people with impairments as society members, it may be worthwhile to focus on policy and market mechanisms and practices in order to better understand the causes and experiences of disabled consumers' vulnerability in the private market realm. Hence, the paper adopts the social model perspective and shifts the focus from an individual to external factors as causes for consumer exclusion and vulnerability in the EU single market.

Firstly, literature and policy regulations concerning consumer information and its accessibility on the one hand, and ableism on the other, are reviewed. Then the design of a broader study, which looks at consumer information as a part of an accessible shopping chain, is introduced. The paper concludes with a discussion of the findings and insights into policy developments and implications for future research.

\section{Consumer Information, Accessibility, and Ableism}

Information is crucial for making consumer decisions (Bettman et al. 1991; Hoffmann and Inderst 2009; Kivetz and Simonson 2000; Nelson 1970) and is often perceived as a precondition for shopping (Hoffmann and Inderst 2009; Kivetz and Simonson 2000). Individuals usually start gathering the information before they leave home and enter retail premises (Barthes 1973; Gabriel and Lang 1995). In this pre-shopping stage, they browse product catalogues and magazines (Vijayasarathy and Jones 2000), and look for information online in business websites (Häubl and Trifts 2000; Peterson and Merino 2003) and user forums (Bickart and Schindler 2001; Eskyte 2019). The information acquisition then continues in public spaces (Ben-Rafael et al. 2006; Rosewarne 2005) and retail premises that are important for choosing a shop and finding a way to get there (D'Astous 2000; Hackett et al. 1993; Otterbring et al. 2014; Passini 1996) and to familiarize with and evaluate products, their features, and price, as well as other attributes (Chang and Wildt 1994; Peck and Childers 2003). While "average" consumers are often overloaded with information (Bettman et al. 1991), people with impairments are rarely fully informed (Eskytè 2019). Lack of information provided in accessible formats such as Braille, audio, large print, sign language, easy-to-read texts and symbols, and text-based information (Waddington 2009) is an important factor shaping their exclusion and vulnerability (Eskyte 2019). 
The European Commission recognizes the need to provide consumers with information (Maastricht Treaty 1992, Art. 153.1; European Council 2012, Art.169.1). A number of regional instruments dealing with certain market sectors or product types address accessibility of consumer information. To begin with, Regulation on Air Travellers' Rights ${ }^{1}$ states that "all essential information provided for air passengers should be provided in alternative formats accessible to disabled persons" (preamble). Likewise, the Directive on e-Privacy ${ }^{2}$ requires providers to "regularly inform disabled subscribers of details of products and services designed for them" (Art. 21f). It positions national regulatory authorities as responsible bodies to "specify, inter alia, the quality of service parameters to be measured and the content, form and manner of the information to be published, including possible quality certification mechanisms, in order to ensure that end-users, including disabled users, have access to comprehensive, comparable, reliable and user-friendly information" (Art. 22.2). The instrument does not distinguish separate measures for disabled and non-disabled consumers but blends them together. It provides an information provision framework about existing accessible goods and services, and a quality and equity framework that regulates access to information.

With regard to instruments dealing with consumer products, the Directive on Medical Products $^{3}$ clearly requires that information about publically available products is provided in accessible formats, in particular in Braille. Such requirement challenges the dominant non-disabled consumer-oriented information provision approach and practice as it goes further than the requirement to label products in national language. In doing so, the Directive demonstrates its awareness of the broadness and diversity of consumers and the need for alternative formats in order to ensure access to information about medical products. Nevertheless, such requirement is explicitly established only regarding medical products and is absent in regulations dealing with non-medical mainstream goods and services. In such a way, the EU communicates to the public a stereotypical misleading attitude that for people with impairments, the most important products are those related to their health or impairment (Eskyte 2019).

The focus on accessibility of consumer information in regional regulations outlining requirements applicable to mainstream goods and services is significantly weaker. The Directive on Consumer Rights ${ }^{4}$ (Art. 5, 6) states that before signing an official contract, the trader should provide the consumer with information such as "the main characteristics of the goods and services $[\ldots]$, the identity of the trader [...], the total price [...] the arrangements for payment [...]." The regulation addresses technical aspects of information presentation and encourages national governments to introduce "language requirements regarding the contractual information, so as to ensure that such information is easily understood by consumer." The regulation, however, does not address accessible formats of the provided information. In a similar vein, the Directive on General Product Safety ${ }^{5}$ notes that information about "risks to consumer health and safety posed by products," which is available to legal authorities, should be available to the general public (Art.16). Nevertheless, even though people with impairments are more likely to experience risks caused by mainstream products (Department of Trade and Industry 2000), the Directive does not address information accessibility and so prevents consumers with impairments from safely using certain products.

\footnotetext{
${ }^{1}$ Commission Regulation 1107/2006/EC on the Rights when Travelling by Air.

2 Council Directive 2009/136/EU on e-Privacy.

${ }^{3}$ Council Directive 2004/27/EC on the Community Code Relating to Medical Products.

${ }^{4}$ Council Directive 2011/83/EU on Consumer Rights.

${ }^{5}$ Council Directive 2001/95/EC on General Product Safety.
} 
The absence of specific agreement on how to balance information presentation needs of "average" and "vulnerable" consumers is one of the factors behind the tensions in product labelling requirements and practice (Waddington 2009). The lack of consensus as well as tested and approved practices leads to exclusionary and discriminatory practices and experiences. Consequently, in some instances, the European Court has had to acknowledge that some consumers will be misled by particular marketing practices, including provided information (Waddington 2009). For instance, while people without vision impairments usually do not experience major challenges when accessing contract information in "small print," for those who have vision impairments or are Blind, this type of consumer informing often causes confusion, risks, and financial disadvantage (Eardley et al. 2009). Nevertheless, the court may not treat it as a discriminatory practice.

Current discourse of the EU consumer information provision leads to imbalance of and inequality between "average" and "vulnerable" market participants. "Vulnerable" consumers and their interests are "sacrificed to the interests of self-reliant consumers in deregulation, market integration, and wider choice" (Weatherill 2011, p. 842). Charitakis (2013) notes that since regional instruments aimed at obliging private entities to provide consumers with information do not address information provision in alternative formats, they are not relevant for disabled people. In other words, even though current EU provisions address consumer information, they shed light on non-disabled market players and deprive disabled consumers' right to an informed choice and decision (Hoffmann and Inderst 2009; Prahalad and Ramaswamy 2004).

Ableism shapes the foundation of how regional and national policy regulations and market players categorize and understand consumers. Goodley (2014, p. 21) proposes that "ableism's psychological, social, economic, cultural character normatively privileges able-bodiedness; promotes smooth forms of personhood and smooth health; creates space fit for normative citizens; encourages an institutional bias towards autonomous, independent bodies; and lends support to economic and material dependence on neoliberal and hyper-capitalist forms of production." It prioritizes and favours people without impairments, and discriminates and marginalizes disabled people (Chouinard 1997). Currently, the evaluation of disabled consumers' vulnerability is shaped around perceived standards of normality and function (Amundson and Taira 2005). The presumed competencies of an "average" consumer who usually has no impairments play a key role in deciding who is a vulnerable market participant and who is not (Edward et al. 2000). In terms of market practices, some research suggests that the assumption of ableism is the dominant reason why shops and retail outlets are accessible, pleasant, and safe for "average" consumers, but often exclude and cause barriers to people with impairments (Baker and Kaufman-Scarborough 2001; Eskyte 2019). Others suggest that manufacturers' focus on users without impairments and "cool" product features is an important reason why availability of accessible mainstream products is limited and shop assistants' awareness of and knowledge about accessibility and disability are insufficient (Eskyte 2013). Taking the existing literature further, the paper employs disabled consumers' accounts regarding consumer information about mainstream retailers and goods and services to challenge legally constructed consumer vulnerability of people with impairments in the European single market.

\section{Methodology}

International qualitative study combined mystery shopping and semi-structured interviews with disabled consumers (Lithuania and the UK) with semi-structured interviews with and 
observations of civil society and private market players (national (Lithuania, the UK) and international (EU)). The accounts shared by disabled consumers provide the foundation for this article and are supplemented by data gathered during interviews with and observations of private market actors. The qualitative data of the two participant groups are used to question current EU policies regarding defining disabled people as vulnerable market participants due to their impairments. Since information is a pre-condition for consumer participation (Bettman et al. 1991; Hoffmann and Inderst 2009), narratives related to the subject of matter are extracted to support the case.

\section{Participants and Locations}

A total sample of thirty-eight people with mobility (m.i.; $n=10$ ), vision (v.i.; $n=10$ ), hearing (h.i.; $n=5$ ), cognitive (c.i.; $n=8$ ), and multiple (mlt.i.; $n=2$ ) impairments and mental health conditions (m.h.; $n=2$ ) participated in the study. Participants were of different gender, age (19-79 years old), and ethnicity, and lived in community settings in urban places.

The study with consumers was conducted in Lithuania and the UK as the countries share differences and similarities that provide "information-rich cases that manifest the phenomenon of interest intensively (but not extremely) [ ... and] seek excellent or rich examples of the phenomenon of interest, but not unusual cases" (Patton 1990, p. 171). Lithuania and the UK are members of the EU; they entered the Union in 2004 and 1973 respectively. They act in the EU economic area under the EU Single Market framework and legislations, and work towards ensuring the fundamental freedoms of the Union to their citizens. Both countries have ratified the CRPD 2006 and the Optional Protocol (26/02/2009; 07/08/2009 and 30/03/2007; 18/08/ 2010 respectively) and are obliged to transfer the duties into national legislations. Lithuania is an Eastern European country with 2.9 million inhabitants (Lietuvos Statistikos Departamentas 2014) and the UK is a Western European country with 64.1 million inhabitants (Office for National Statistics 2014). 8.03\% of Lithuanians are identified as disabled (Bringing Neighbours Closer 2012), and 19\% of total British population are ascribed to this category (Papworth Trust 2014). Lithuania is a post-Soviet Union country and has a short history of a small, still developing market. The country is dealing with challenges such as unbalanced economy, fragmented and unevenly developed market sectors, blurry patterns of import and export, and a lack of instruments regulating market relations (Bertelsmann Stiftung BTI 2010; Hohnen 2003). On the other hand, the UK has a long experience of playing a leading role in the European and world economy and international commerce and finance (Mollan and Michie 2012; Rota and Schettino 2011). Thatcher's era (1979-1990) and the new approach to economic policy introduced privatization, tax changes, and reformed industrial relations (Crafts 2002). This positioned the UK as a long-term competitive economy.

\section{Mystery Shopping and Qualitative Interviews}

Mystery shopping and qualitative interviews were employed to investigate disabled consumers' experiences and to use these to challenge legally constructed consumer vulnerability as an outcome of impairment. Mystery shopping is a form of participant observation where the researcher interacts with the research participants being observed (Miller 1998). It differs from subject observation as defined in anthropology studies (Hudson et al. 2001) and is often employed to research mainstream market (Miller 1998). Adoption of the method in this study enabled identifying different elements of the service delivery process on natural conditions 
(Grove and Fisk 1992) and served as a reliable tool to test whether disabled consumers are treated equally or are discriminated against (Morrall 1994; Wiele et al. 2005). It assisted in overcoming the discrepancy between real and reported behaviour (Friedrichs et al. 1975) and provided the participants with more control and power over the research process (Eskyte 2019).

Participants in Lithuania and the UK were approached and recruited via gatekeepers in Disabled People Organizations, emailing lists, e-newspapers, and Facebook. Those who expressed interest in the study were contacted in advance and the information was provided in formats most accessible for each individual. The potential participants were provided with an accessible information sheet and were offered time to decide about their participation, ask questions, and to discuss the aim and process of the research and findings dissemination (Barnes 1992; Barnes and Mercer 1997; Stone and Priestley 1996).

Prior to each mystery shopping event, information provided at the initial stage was repeated and when needed, sign interpreter's service was used. Despite different communication mediums, all participants were introduced to the purpose of the study, and the form and objectives of mystery shopping and interviews. It was emphasized that the focus of the inquiry is not on individuals' shopping "performance," but on barriers and potentials in the public environment, transport infrastructure, and retail premises. The participants decided which, when, and how many shops they would like to visit and where to meet for the mystery shopping and the interviews. This served in providing the informants with more control and power over the research process (Barnes 1992). All but three consumers preferred meeting near their home and we travelled to their chosen retail outlets together. Three participants (Lithuania $n=2$, UK $n=1$ ) visited shops individually and we had an interview afterwards.

The duration of the trip to shops and of mystery shopping varied. Some participants reached chosen retail outlets in less than 10 minutes and for others, the journey took between 10 and 45 min. In a similar vein, some consumers did not interact with shop personnel and spend between five and 10 minutes in the shop, and others communicated with shop assistants and their mystery shopping was longer than one hour. Around half of the participants preferred going to grocery or clothes shops and others to shops selling Information Communication Technology products; the majority of the informants bought some items during the mystery shopping. Those who bought items perceived me as a source of assistance in the shopping process, rather than a purchase decision-maker or assistant in making consumer decisions. As an example, Ramune (female, LT, age 18-40) asked me to describe a coat colour; Katrina (LT, age 18-40) asked me to reach for some products in the pharmacy; Daphne (female, UK, 1840) asked for some assistance in grocery shopping; and Rachel (female, UK, age 41-64), Alison (female, UK, age 18-40), Jack (male, UK, age 41-64), and Peter (male, UK, age 1840) asked for assistance in the shopping process when different barriers occurred.

Semi-structured interviews followed the mystery shopping. Great care was taken to use accessible research tools and communication means. To illustrate, when interviewing, techniques such as simple words and pictures, short sentences, asking one question at a time, and rephrasing questions were used. This ensured accuracy (Finlay and Lyons 2001). Self-directed reflections by the interviewee (Rodgers 1999) were also encouraged. The interview guide included a number of questions addressing key stages of an accessible shopping chain (Eskyte 2019). The questions were followed by a list of probes and observation data from the mystery shopping. This allowed for explaining the questions (Bryman 2012) and ensured further elaboration and clarity of the provided accounts (Gray 2009; Ruane 2005). The main attention was dedicated to consumer experience, when market expands beyond the exchange process in 
the shop, positioning technical product accessibility as a secondary issue. All interviews except for one via Skype were audio-recorded and transcribed. With regard to consumer information acquisition, the participants were invited to discuss and share their experiences regarding the way they find out and learn about shops, their location, and accessibility of premises as well as product availability and accessibility.

Thematic data analysis approach was adopted. The data analysis process involved "careful reading and re-reading" (Rice and Ezzy 1999, p. 258) of research material aiming to identify the main themes. Alongside the pattern identification within the data (Fereday and MuirCochrane 2008), individual or unique cases were noted down. The interviews were repeatedly read, aiming to find commonalities or contradictions among the unique cases.

\section{Information About Location of Retail Outlets}

Information about retail outlets and their location is important to consumers with or without impairments. However, insufficient and often absent provision of such information in accessible formats limits the number of shops discovered and visited by people with impairments, and disrupts the quality of their shopping experience. Research data suggest that currently, a "standard" format of informing about retail outlets and their location is readily available, but is not to be found in Braille, large print, audio information, or easy-to-read texts and symbols. In this respect, people with mobility impairments are dependent upon "average" consumeroriented channels such as radio, television, Internet, newspapers, and promotional flyers. Access to information for people with hearing impairments is usually limited to the Internet, in particular, shop-related reviews, and discussion forums, as well as printed materials. Shoppers with vision impairments usually learn about retailers via Internet, radio, and television, as other information sources are often inaccessible. To illustrate, Ramune (v.i., age 1840 , LT) shared an example of how such things as paper glossiness and small font size used in promotional flyers prevent her from learning about available shops and making an informed decision about where to buy:

I find all these promotional flyers in my post-box and I believe they are informative and provide more options in terms of products and price. But they are printed on a glossy paper and letters are small. Although I could use my loupe, the glossiness of the paper makes it impossible to see and read the information. Even though all these papers come to my house, they do not come to my brain and do not expand my knowledge either about products or about shops.

On the other hand, informants with cognitive impairments have the opposite experiences. For them, promotional flyers are an important and accessible source of information about shops in their combination of visual and written information. As an example, Maryte (c.i., age 65+, LT) said:

It is very good that I get brochures. I like pictures and also I like that they draw the name of the shop in the same way as they hang it above the entrance. It is much easier to not get confused.

The use of information sources aimed at "average" consumers excludes some people with impairments from learning about and visiting retail outlets. It makes them aware that they are not only excluded from physical participation in certain shops, but also know less compared with those who are able to access the information. Kaufman-Scarborough (2016) argues that 
while private market actors do not purposefully seek to limit disabled consumers' participation, but that due to limited knowledge about disability and accessibility, they unintendedly exclude certain groups of people, appearing to exhibit some form of discrimination against consumers with impairments. Maryte's account suggests that private market practices, shaped by ableism and limited knowledge about accessibility, create unintended inclusion practices in that more access is provided for shoppers with certain impairments. Since promotional flyers are aimed at promoting goods, services, or providers in a cost-effective way so that consumers are persuaded to spend, it is unlikely that people with cognitive impairments and mental health conditions were considered as one of the target groups for promotional flyers. Nevertheless, having limited knowledge of this diverse consumer segment, and choosing promotional leaflets for "average" consumers as a means of communicating, those shoppers to whom written and pictorial information is the most accessible are unintentionally better provided for. Differences in promotional leaflet-related experiences of people with vision and cognitive impairments suggest that the same information source is approached and experienced differently by people with different impairments and "one size does not fit all."

Retailers often rely on their communication practices to attract potential consumers to the high street. However, the chosen communication does not necessarily benefit disabled shoppers. As an example, some participants with vision impairments noted that due to the absence of accessible information about shops in the high street, their shopping options are limited. To illustrate, Rolandas (v.i., 41-64, LT) said:

I go only to few shops that I really know and know where they are, because there are lots of other shops that I even cannot think about or imagine.

For others, a lack of accessible information about shops in the high street is a barrier that prevents a free and independent shopping process, causes confusion, and wastes time:

It is always difficult finding a specific shop along the street. If I am looking for HMV, then probably I will walk in two or three different shops, before I find HMV (Jack, v.i., 41-64, UK).

Narratives of other participants with vision impairments suggest that such experience is a common part of their shopping and one of the reasons why they may need to seek the assistance of people without vision impairments. As an example, echoing other informants' experiences, Ramune (v.i., 41-64, LT) reported that she visits new cafes or pizzerias only when her daughter accompanies her. Similarly, Nick (v.i., 41-64, UK) said that his shopping is much more pleasant and time-efficient, and less stressful when he is in town together with a friend or a neighbour who does not have vision impairments.

As well as assistance provided by other individuals, some participants with vision impairments employ senses of smell or hearing, intuition, and learned routes as a means of finding a way to wanted retail outlets. To illustrate, Jack (v.i., 41-64, UK) said:

I find myself using a sense of touch and a sense of smell and sounds. So there's a shop called Lush, and you can smell that from several shops away. And I hardly ever go into that shop, but it serves as a sort of landmark for the shops around it. HMV I would usually find by the sound because they'll usually be playing music. But I guess the difficulty is, it's not the only shop that plays loud music. So there are a couple of clothes shops nearby. If I'm trying to find a shoe shop, I can usually do that by smell. So you step inside the shop, breathe in, and if I can smell leather, then I'm probably in a shoe shop. 
Consumers with mobility impairments noted that advertising banners and A-frames used by some retailers require them to move towards more crowded pedestrian areas in which it is more difficult to manoeuver in. In addition, wheelchair users reported that since shop names and other information are located at the eye-level of a standing person, they have to move slower and be more focused while they look for a shop. At the same time, they need to be careful to avoid such things as potholes or a crumbled pavement:

It would be absolutely fantastic if shops mark their name on the floor outside the entrance. I sometimes struggle to lift my head up, so if I do not know the shop or where I am, I have to either guess or ask people in the street (Karina, m.i., 18-40, LT).

Together with other studies of this research, the examples insinuate that while non-disabled consumers are overloaded with information (Bettman et al. 1991), disabled people, due to limited availability of information about shops provided in alternative formats, are rarely free to choose where to purchase goods and services. Unequal information provision divides nondisabled and disabled people as information-consumers and isolates the latter group even to the extent that some retailers unintentionally choose information and consumer communication that is inaccessible for some disabled people (Eskyte 2019). By prioritizing "average" consumers, having a great control over content and manner of the provided information (Kivetz and Simonson 2000) and lacking a regulatory framework regarding accessibility of information about shops and private retailers create shopping contexts that exclude disabled people from knowing about and purchasing in certain shops. In such a way, they shape a map of the private market where some areas are available for people with impairments, while in other areas, they are invisible or absent. Elimination from free choice in where to shop transforms disabled people from potentially active, independent, and financially contributing market participants into passive and vulnerable consumers, often invisible in the European single market.

\section{Information About Accessibility of Retail Premises}

The lack of information about the accessibility of retail premises causes inconvenience, prevents shopping in some shops, and often leads to vulnerability experiences. Participants with hearing and cognitive impairments and mental health conditions did not find this aspect relevant. On the other hand, a great number of informants with vision and mobility impairments reported this topic as particularly important. The majority shared examples from personal experience when, after arriving at the shop, they either could not enter retail premises or face various barriers. To illustrate, Kristupas (m.i., 18-40, LT) said:

After the accident [when he became a wheelchair user] it used to happen very often that I actually come to the shop, but I can't get in, because there are steps and no ramp. Now it doesn't happen, because I know which shops are accessible, but back then I had to turn around and look for another shop.

For some consumers, the absence of this kind of information causes stress and emotional and psychological tensions. For instance, Daphne (m.i., 18-40, UK) and some other participants with mobility impairments referred to "the feeling of uncertainty that accompanies during the whole trip to the shop," that is particularly strong when travelling to unknown or new shopping sites. Some participants with vision impairments reported a constant tension and anxiety that they feel before going to unfamiliar shops and especially big shopping malls. 
In this respect, echoing positions of other informants with vision and mobility impairments, Pranciska (v.i., 41-64, LT) noted that provision of information about accessibility at retail premises would allow identifying accessible shops, choosing where to buy, and avoiding unpleasant experiences. However, the absence of such information eliminates consumers from making informed purchase decisions and experiencing shopping as a pleasure. To illustrate, Pranciska said:

They could find a little niche ... A niche where they say whether the shop has stairs, lift, mirrors, day lighting and so on. It would be so much better. Then I could choose if I can go to that shop. Because for me personally to go to the shop with bad lighting, mirrors and steps is a tragedy. I would never go. Yes, it happens that I go to such shops, because there is no way to find out.

In response, disabled people employ various strategies and means that enable them to avoid or lessen exclusion and vulnerability when shopping and to be more independent consumers. Some participants noted that before they travel to an unfamiliar shop, they seek advice from other people with similar impairments or browse for information online. Karolis (m.i., age 4164, LT) was the only informant who said that before he goes to a new retail outlet, he phones the shop to ask about its accessibility and facilities for wheelchair users. Although a considerable number of the interviewees said that despite the absence of such information they take a risk and travel to unknown shops, the majority of the participants, especially those with severe impairments and older people, noted that they prefer going to familiar and "tested" shops. As an example, Hilda (v.i., 65+, LT) said that shopping in familiar shops makes her more independent:

Oh no, I don’t go to new shops alone. I have my own shops where I usually go. Well, there are few shops that I am familiar with, so I go only there. It's complicated enough.

For someone like Hilda, who due to limited financial resources and narrow social network and social support is limited in participating in social activities, is unable to gain information about shops and their accessibility, and does not have the confidence to visit new retail outlets, insufficient provision of accessible information has a broader implication on everyday life. Being unable to learn about different retail outlets, she is denied the possibility to exercise choice and control (Bettman et al. 1991), to shape and communicate her identity, engage with social networks and communities (Miller et al. 1998), and to experience shopping as a leisure (Graham et al. 1991) and pleasure (Campbell 1997).

\section{Information About Products}

Regional and national policy regulations insufficiently address accessibility of product information, and private retailers focus primarily on non-disabled consumers. The synergy of the two factors creates consumer participation contexts that prevent consumers with impairments from making informed product decisions. With regard to the acquisition of product information prior to consumer interaction in retail premises, people with impairments experience a variety of barriers across the board of available information sources. To begin with, participants with hearing impairments reported that information on the radio is usually inadequate for them. With regard to television, while the British consumers did not provide examples of major barriers, Lithuanians shared experiences of constant exclusion. To illustrate, Justas (LT, 18-40) said: 
I am not a big fan of TV, but sometimes I think it would be nice if they captioned not only news, but also different programmes, including ads. Although they [advertisements] are a "fish-hook" of the devil, sometimes they may provide you with useful information.

Herbertas (h.i., age 65+, LT) said that because of limited or absent subtitles, only at home is he able to learn about products and services advertised on TV because he uses his homemade speakers:

Sometimes there are great advertisements on TV, but if I am not at home and thus I do not have my special speakers, I am excluded from what other people in the room hear. It is annoying. Once I visited my son and saw an advertisement about a special offer for quite rare flowers. I did not hear and my son was not in the room at that moment, so he could not re-say what was on that adverts. Then I came back home and watched TV for almost two days while finally saw the same adverts and finally could hear it. This was very tiring, but worth it.

The Lithuanian Government defines captioning, notes, sound recording, and sign language as an important means for providing more access to participation in cultural life, recreation, and different leisure activities (Lietuvos Respublikos Vyriausybė 2012). Nevertheless, the legal requirements are applied only to information provision in the field of education (Lietuvos Respublikos Vyriausybe 2005). The switch from analogue terrestrial to digital television in 2012 provided an opportunity to increase accessibility of television. However, none of the related legislations were amended. Consequently, since broadcasters are the main responsible agents in choosing which programmes and movies should be captioned, the majority of TV programmes and all advertisements are inaccessible for people with hearing impairments. The situation in the UK is different. Here the Code of Television Access Service (Ofcom 2010) outlines the requirements for subtitling, sign language, and audio description that apply to television services. It is not surprising then that although the British participants noted that captioning "is not always available," the majority shared positive experiences and identified the service as "good."

Participants with vision impairments further narrated how current practices of providing product information limit their consumer control and choice. They unanimously noted that sources such as promotional leaflets and advertisements in newspapers, public spaces, and shop windows usually do not fulfil the function, as they are shiny, glossy, or in small print. For instance, for Pranciska (v.i., age 41-64, LT), advertisements in newspaper back pages often are too colourful and tire her eyes. Christine (v.i., age 18-40) said that the only way she finds out about products advertised in newspapers is if someone without vision impairment reads out loud the adverts and describes the products. These and similar narratives were common, and echo the discussion on information about shops. They illustrate how information provision practices directed at the "average" shopper are unusable for people with impairments. This limits their shopping choices and consumer independency, and excludes them from making informed market decisions.

When talking or learning about products, the participants often referred to text messages or emails sent by retailers. The majority of them described these information sources as intrusive and annoying. Three Lithuanian and one British participant with vision impairments noted that sometimes information coding in promotional emails is incompatible with their assistive software. Consequently, even though this kind of consumer information is available to them, 
because of technical incompatibility it is inaccessible and prevents them from finding out about and choosing from the advertised items. On the other hand, several informants with cognitive impairments and mental health conditions said that they prefer this information source. Indeed, a great part of their shopping decisions are founded on promotional text messages and emails sent by retailers. For instance, Maryte (c.i., age 65+, LT) said:

I leave my telephone number and then I get a text message about discounts and where I should go to get these discounts.

Albinas (m.h., age 41-64) echoed:

They send [information] to my email. Many shops have my email address and then they send me information and I know where and what can be found.

It seems that pictures, with specific and not overloaded information about the products, may be some of the factors shaping the preference for this information source by consumers with cognitive impairments. However, incompatibility between information provision and consumer attraction practices in the pre-shopping stage and actual consumer service in some shops in Lithuania suggested tensions between practices and experiences in the two shopping stages. Specifically, the choice of Ignas (c.i., age 18-40), Andrius (c.i., age 18-40), Salomeja (c.i., age $65+$ ), and some other participants with cognitive impairments as to which shop to go to for the mystery shopping was based on the received promotional text messages or emails. Contrary to the attractive and accessible information, shop assistants' behaviour was unwelcoming and excluding. Some of them avoided serving shoppers with cognitive impairments and others used many technical terms and jargons when describing products such as a hairdryer or an mp3 player. In the majority of cases, the atmosphere was unpleasant and patronizing, and the service delivery contradicted principles of a personalized service. The participants noted that such behaviour causes anxiety, frustration, misleading shopping choices, a feeling of being treated as a different or less important consumer, and may encourage the avoidance of certain retail outlets. Stigma that is often associated with cognitive impairments (Garand et al. 2009) and mental health conditions (Clement et al. 2015; Soghoyan and Gasparyan 2017), the hierarchy of disabled people as consumers, and the limited training for shop assistants on disability, accessibility, and consumer equality (Eskyte 2019) are all key factors shaping the practice.

As in the case of information about shops, the majority of consumers with mobility impairments reported having access to the majority of information sources that are targeted at and accessible to non-disabled people. Statements such as "usually there are no problems" (Vakare, m.i., age 61-64), "no, I do not face any problems" (Pranas, m.i., age 18-40), or "I have no problem with this" (m.i., UK, age 41-64) illustrate their experiences.

Aiming to overcome ableist product information provision practices, people with impairments employ various coping strategies. Some participants with vision impairments reported that they use a magnifying glass, while others referred to accessible software. In addition, echoing accounts of other participants with vision impairments, Christine (v.i., age 18-40) noted that her partner describes products and services advertised on the Internet, newspapers, journals, and promotional leaflets. Herbertas (h.i., age 65+) showed his special "homemade" speakers that enable him to listen to the radio and to watch TV, and Justas (h.i., age 18-40) and Chris (h.i., age 18-40) noted that they download subtitles for movies or series from the Internet. Nevertheless, communication with other disabled people and sharing ways to overcome ableist barriers are the most important. To illustrate, Juozas (v.i., age 41-64) noted: 
We get information in the same way as you, non-disabled people, get. The only thing is that not all information is accessible for us. However, what is inaccessible via official channels is accessible via own and informal channels and ways.

These informal channels usually are disabled peers in different disabled people's clubs, Disabled People's Organizations, day care centres, online forums, and discussion groups, as well as family members and friends. Juozas' experiences implicitly demonstrate that even though the EU and national governments are moving towards providing more accessibility for disabled people in general, the actions that have been taken regarding consumer information are insufficient. They do not holistically address essential elements needed for ensuring that consumer information is accessible for the greatest variety of people. Consequently, this leads to inequality and limited participation of those shoppers, who do not meet standards of an "average" fit and healthy individual.

\section{Discussion}

In order to gain a better understanding of why positioning individual's impairment as a core reason for consumer vulnerability is fundamentally wrong, the aim of this paper was to demonstrate how market structures and business practices exclude and marginalize people with impairments, and shape their vulnerability in retail markets. The findings of the study show that business focuses on non-disabled consumers in that information provision practices aim at informing and seducing people without impairments play a key role in eliminating disabled people from informed decisions about where and what to purchase. They also restrict their choice and the opportunity to experience shopping as leisure or a form of socialization, and prevent overall participation in the mainstream private market. The study approached consumer information in a broader way than just product information and found evidence that ableism is an underpinning philosophy behind strategies and practices that inform people about available providers of goods and services, both at the pre-shopping and shopping stages. If a consumer with impairment is prevented from acquiring shopping information at any point, they are eliminated from an informed decision and "locked within" providers that accidently are more accessible. Nevertheless, disabled consumers are not passive observers of inequality and exclusion. On the contrary, whenever possible, they employ various strategies that enable them to be more active and independent. It would be misleading to state that business players deliberately employ inaccessible communication practices that cause people with impairments to become vulnerable. Yet a narrow understanding of and limited emphasis on consumer information in policy regulations, as well as the historically and culturally constructed portrayal of a consumer as a healthy, fit, middle class person (usually male), mean that the market is geared towards the needs and preferences of this audience. Unfortunately, disabled people are not a part of this audience, neither are their information needs seen to be important.

The findings contribute to the literature in several ways. First of all, whereas previous research into consumer information and disability approached the topic from a legal perspective or shed light on the experiences in retail outlets by people with vision impairments, this study approached it from a disabled consumer perspective in the retail market. That is to say, how people, who do not meet a pre-defined definition of an "average" consumer because of their impairments, experience market relations and consumer participation through current information provision/acquisition practices. Using a diverse sample from two countries that are 
different in terms of market relations and disability policy, it was observed that despite national differences and type of impairment, disabled people are constantly excluded from barrier-free consumer information acquisition; this leads to segregation in certain market niches or retailers. These results are, therefore, consistent with the hypothesis that neither disabled consumers nor their information needs are seen as a priority by business players, but they also reveal that limited training and awareness of disability and accessibility are an important factor shaping disabled consumers' vulnerability. A second contribution to the literature lies in the fact that the study approached consumer information in a broader way than just product information in a retail outlet. It was suggested that for an informed decision by a disabled consumer, information about a product and a retail outlet has to be provided in alternative formats and must address accessibility both in pre-shopping and shopping stages. Thirdly and most importantly, the evidence suggests that the vulnerability of disabled consumers is not a direct outcome of their impairments or physical features, but is shaped by current capitalist market structure, i.e., a limited and narrow policy framework regarding information provision, the inappropriate business practice, and traditional means of informing consumers, as well as insufficient training in recognition and awareness of disability and accessibility for service providers and product developers (Fig. 1).

What are policy implications of this research? While the sample of thirty-eight participants from two EU Member States does not provide an overall picture representing the phenomenon and much needed policy development across the EU, it provides valuable insight into the origin of disabled consumers' vulnerability and identifies issues that policy makers, academics, and the disabled people's movement need to investigate further.

To begin with, it is clear that the official shift from regarding disabled people as passive users of health and social care services or consumers of "special" impairment-related products to active participants of the mainstream private market has taken place both in European and national policy discourses. However, despite this definitive shift, the content of the concept

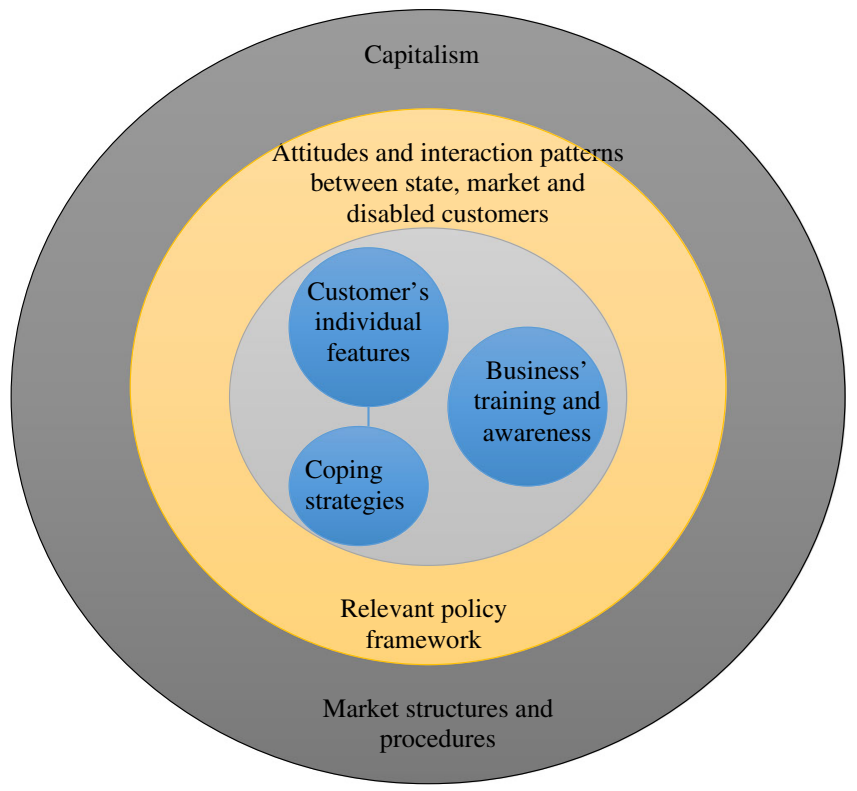

Fig. 1 Factors shaping disabled consumers' vulnerability 
and the measures around it are premised on an individual model of disability and the position of a disabled person as a "vulnerable" consumer because of impairment. The recognition of distortive and ableist market practices that play on a disabled person's vulnerability when engaging in market relations is unacceptable. The findings indicate that such positioning prevents identification of the real and often unobservable causes of a disabled consumer's vulnerability and draws attention to wrong measures for tackling marginalization and restricted participation. Moreover, it creates division and inequality between disabled and non-disabled market participants. Clearly, the study does not support the idea that European and national policy makers deny the susceptibility of the disabled people to consumer vulnerability. It does, however, note that an individual's impairment should not be treated as one of the main reasons for this vulnerability, and that a stronger emphasis should be put on inconsiderate market practices. Division of consumers into "average" and "vulnerable" will not solve inequality or vulnerability, but incorporating accessibility requirements in generic consumer participation and protection- and product development-related regulations may encourage an ontological and epistemological shift that tackles deeper market structures and interaction patterns between the state, market, and disabled people.

Alongside definitive changes and legally establishing the disabled consumer's position in the market, realistic policy requirements and regulations oriented towards changes in retail practice are essential. The vulnerability of disabled consumers will neither disappear nor decrease if product developers and service providers lack the knowledge about and awareness of disability and accessibility. While some retailers provide training for "special" shop assistants aimed at serving disabled people, the practice is more an exception than a rule, and has a number of negative and often discriminatory aspects (Eskyte 2019). Since it is the Member States' responsibility to provide framework within which "private entities that offer facilities and services which are open or provided to the public take into account all aspects of accessibility for persons with disabilities" (CRPD 2006; Art. 9), national governments should adopt an overall approach to accessibility of consumer participation, which consists of a number of overlapping and complementary dimensions that if needed are able to function individually. To begin with, in tackling limited knowledge about accessibility, some form of encouragement should be given for higher education institutions that educate managers, marketing, consumer information, and advertising specialists to consider and incorporate accessibility as a standard part of the curriculum. However, it is well known that public bodies often have very limited understanding of what accessibility means (Lawson and Woodin 2012). Consequently, in the light of the requirement of Article 4 (CRPD 2006) to "closely consult" and "actively involve" Disabled People's Organisations," national governments should create a platform enabling civil society to act as an independent advisory body regarding the implementation of accessibility provisions in business practice. Disabled people's involvement in educating professionals and not just evaluating their work when inaccessibility issues arise is likely to create a scene for the two stakeholder groups to engage in a dialogue, share and innovate knowledge, and position accessibility as a common goal.

Alongside guidance and training, setting timeframes and concrete targets or actions for the achievement of accessibility of consumer information is important. As an example, depending on a business size, retailers could be provided with a certain timeframe within which they have to provide information, including that on accessibility of goods, services, and retail premises in different alternative formats. Aiming to achieve compliance with accessibility objectives or requirements and to gauge progress towards improved accessibility, adequate supervision and 
monitoring are important. On the one hand, a public body comprising of policy makers, business players, Disabled People's Organizations, different professionals, and independent experts or advisors could be an important body, ensuring that new business activities, including consumer information, meet accessibility requirements and become usable by as many people as possible. On the other hand, such a public body could play a leading role in informing the public about the progress towards agreed goals, and encouraging other businesses to follow the examples of good practice.

While the study provided some useful insight into this under-researched phenomenon, there is a strong need for future research to further the knowledge. First, there is a knowledge lacuna, from the social model of disability perspective, regarding the consumer behaviour and participation of people with impairments. Understanding how market structures and procedures shape shopping and consumer behaviour, and not only relying on the description of shopping experience and consumer behaviour of people with impairments, is crucial for identifying ways towards more inclusion and equality. In addition, accessibility provisions are often associated with high costs. While some market sectors (mainly producers) are becoming aware that accessibility provisions are not necessarily costly and that they bring a number of benefits and advances, this is not the case in terms of consumer information. Consequently, further research is needed to investigate how accessible consumer information affects market relations and participation.

\section{Legislation}

\section{United Nations}

The United Nations Convention on the Rights of Persons with Disabilities (CRPD) 2006

\section{European Union}

Regulation 1107/2006/EC on the Rights when Travelling by Air

Directive 2009/136/EU on e-Privacy

Directive 2004/27/EC on the Community Code Relating to Medical Products

Directive 2011/83/EU on Consumer Rights

Directive 2005/29/EC on Unfair Business-to-Consumer Commercial Practices in the Internal Market

Treaty on the Functioning of the European Union 2012

Treaty on European Union 1992

\section{United Kingdom}

The Consumer Protection from Unfair Trading Regulations 2008

\section{Lithuania}

Elektros istatymas 2012

Funding This work was supported by the Marie Curie Initial Training Network.

Open Access This article is distributed under the terms of the Creative Commons Attribution 4.0 International License (http://creativecommons.org/licenses/by/4.0/), which permits unrestricted use, distribution, and reproduction in any medium, provided you give appropriate credit to the original author(s) and the source, provide a link to the Creative Commons license, and indicate if changes were made. 


\section{References}

Advani, S., Zientara, P., Shukla, N., Okafor, I., Irick, K., Sampson, J., et al. (2017). A multitask grocery assist system for the visually impaired: Smart glasses, gloves, and shopping carts provide auditory and tactile feedback. IEEE Consumer Electronics Magazine, 6, 73-81.

Amundson, R. (2005). Disability, ideology and quality of life: A bias in biomedical ethics. Cambridge: Cambridge University Press.

Amundson, R., \& Taira, G. (2005). Our lives and ideologies: The effect of life experience on the perceived morality of the policy of physician-assisted suicide. Journal of Disability Policy Studies, 16, 53-57.

Baker, S. M., Gentry, J. W., \& Rittenburg, T. L. (2005). Building understanding of the domain of consumer vulnerability. Journal of Macromarketing, 25, 128-139.

Baker, S. M., \& Kaufman-Scarborough, C. (2001). Marketing and public accommodation: A retrospective on title III of the Americans with disabilities act. Journal of Public Policy and Marketing, 20, 297-304.

Baker, S. M., Labarge, M., \& Baker, C. N. (2016). Consumer vulnerability: Foundations, phenomena, and future investigations. In K. Hamilton, S. Dunnett, \& M. Piacentini (Eds.), Consumer vulnerability: Conditions, contexts and characteristics. Oxon: Routledge.

Baker, S. M., Stephens, D. L., \& Hill, R. P. (2001). Marketplace experiences of consumers with visual impairments: Beyond the Americans with Disabilities Act. Journal of Public Policy and Marketing, 20, 215-224.

Barnes, C. (1992). Qualitative research: Valuable or irrelevant? Disability, Handicap and Society, 7, $115-124$.

Barnes, C., \& Mercer, G. (1996). Exploring the divide: Illness and disability. Leeds: The Disability Press.

Barnes, C., \& Mercer, G. (1997). Breaking the mould? An introduction to doing disability research. Doing disability research, 1, 1-4.

Barnes, C., \& Mercer, G. (2003). Disability. Cambridge: Polity Press.

Barnes, C., \& Mercer, G. (2005). Disability, work, and welfare: Challenging the social exclusion of disabled people. Work, Employment and Society, 19, 527-545.

Barthes, R. (1973). Mythologies. London: Paladin Books.

Ben-Rafael, E., Shohamy, E., Hasan Amara, M., \& Trumper-Hecht, N. (2006). Linguistic landscape as symbolic construction of the public space: The case of Israel. International Journal of Multilingualism, 3, 7-30.

Bertelsmann Stiftung BTI. (2010). Lithuania country report. Gütersloh: Bertelsmann Stiftung.

Bettman, J. R., Johnson, E. J. \& Payne, J. W. (1991). Consumer decision making. In Robertson, T. S. \& Kassarjian, H. H. (Eds.), Handbook of consumer behavior (pp. 50-84). Englewood Cliffs, NJ: Prentice-Hall.

Bickart, B., \& Schindler, R. M. (2001). Internet forums as influential sources of consumer information. Journal of Interactive Marketing, 15, 31-40.

Bringing Neighbours Closer (2012). Neigaliuju idarbinimo galimybiu plètra, Klaipéda.

Bristor, J. M., Lee, R. G., \& Hunt, M. R. (1995). Race and ideology: African-American images in television advertising. Journal of Public Policy and Marketing, 14, 48-59.

Bryman, A. (2012). Social research methods. Oxford: Oxford University Press.

Campbell, C. (1997). Shopping, pleasure and the sex war. The shopping experience, 1, 166-176.

Campbell, J., \& Oliver, M. (1996). Disability politics: Understanding our past, changing our future. London: Routledge.

Chang, T.-Z., \& Wildt, A. (1994). Price, product information, and purchase intention: An empirical study. Journal of the Academy of Marketing Science, 22, 16-27.

Charitakis, S. (2013). An assessment of the scope of the European Accessibility Act: How it can be expanded? Unpublished.

Chouinard, V. (1997). Making space for disabling differences: Challenging ableist geographies. Environment and Planning D: Society and Space, 15, 379-387.

Clement, S., Schauman, O., Graham, T., Maggioni, F., Evans-Lacko, S., Bezborodovs, N., et al. (2015). What is the impact of mental health-related stigma on help-seeking? A systematic review of quantitative and qualitative studies. Psychological Medicine, 45, 11-27.

Coleman, R. \& Lebbon, C. (2010). Inclusive design. Helen Hamlyn Research Centre, Royal College of Art.

Crafts, N. (2002). Britain's relative economic performance, 1870-1999. London: The Institute of Economic Affairs.

D'Astous, A. (2000). Irritating aspects of the shopping environment. Journal of Business Research, 49, 149-156.

Department of Trade and Industry. (2000). A study of the difficulties disabled people have when using everyday consumer products. London: Department of Trade and Industry.

Eardley, T., Bruce, J., \& Goggin, G. (2009). Telecommunications and community wellbeing: A review of the literature on access and affordability for low-income and disadvantaged groups. Australia: University of New South Wales Consortium. 
Edward, P. C., Almeida, M. D., Gulmann, P. \& Jj, J. (2000). Case C220/98, Estee Lauder Cosmetics GmbH \& Co. OHG v. Lancaster Group GmbH. Retrieved from: http://curia.europa.eu/juris/liste.jsf?language= en\&num=c-220/98. Accessed 29 August 2014.

Eskytè. (2019). Disability and shopping: customers, market and the state. New York, NY: Routledge.

Eskyte, I. (2013). Shopping accessibility: Between the ideal and the real. In NNDR2013-12th Research Conference. Turku: Nordic Network of Disability Research.

European Commission. (2011). The 2012 ageing report. Underlying assumptions and projection methodologies. Brussels: DGECFIN, AWG, Economic Policy Committee.

EUROSTAT. (2009). Consumers in Europe. Retrieved from: http://ec.europa.eu/consumers/archive/strategy/ consumers_europe_edition2_en.pdf. Accessed 26 September 2013.

Fereday, J., \& Muir-Cochrane, E. (2008). Demonstrating rigor using thematic analysis: A hybrid approach of inductive and deductive coding and theme development. International Journal of Qualitative Methods, 5 , 80-92

Ferri, D. (2010). The conclusion of the UN convention on the rights of persons with disabilities by the EC/EU: Some reflections from a 'constitutional' perspective. Verona: Università di Catania.

Fineman, M.A. (2010). The vulnerable subject and the responsive state. Emory Law Journal, 60, $251-276$.

Fineman (2011). The vulnerable subject: Anchoring equality in the human condition. In Transcending the boundaries of law: Generations of Feminism and Legal Theory (pp. 161-175). Oxon: Routledge.

Fineman, M. (2004). The autonomy myth a theory of dependency. New York, NY: The New Press:

Fineman. (2012). Elderly as vulnerable: Rethinking the nature of individual and societal responsibility. The Elder Law Journal, 20, 71-112.

Finlay, W. M. L., \& Lyons, E. (2001). Methodological issues in interviewing and using self-report questionnaires with people with mental retardation. Psychological Assessment, 13, 319-335.

Friedrichs, J., Lüdtke, H., Derr, N., \& Gallasch, A. (1975). Participant observation: Theory and practice. Farnborough: Saxon House.

Gabriel, Y., \& Lang, T. (1995). The unmanagable consumer. Contemporary consumption and its fragmentation. London: Sage Publications.

Garand, L., Lingler, J. H., Conner, K. O., \& Dew, M. A. (2009). Diagnostic labels, stigma, and participation in research related to dementia and mild cognitive impairment. Research in Gerontological Nursing, 2, 112-121.

Gilson, E., 2011. Vulnerability, ignorance, and oppression. Hypatia, 26(2), 308-332.

Goodley, D. (2014). Dis/ability studies - Theorising disablism and ableism. London: Routledge.

Graham, D. F., Graham, I., \& Maclean, M. J. (1991). Going to the mall: A leisure activity of urban elderly people. Canadian Journal on Aging/La Revue canadienne du vieillissement, 10, 345-358.

Gray, D. E. (2009). Doing research in the real world. London: Sage.

Grove, S. J., \& Fisk, R. P. (1992). Observational data collection methods for services marketing: An overview. Journal of the Academy of Marketing Science, 20, 217-224.

Hackett, P. M. W., Foxall, G. R., \& Van Raaij, W. F. (1993). Consumers in retail environments. Advances in Psychology, 96, 378-399.

Haines, A., Kovats, R. S., Campbell-Lendrum, D., \& Corvalán, C. (2006). Climate change and human health: Impacts, vulnerability and public health, 120(7), 585-596.

Häubl, G., \& Trifts, V. (2000). Consumer decision making in online shopping environments: The effects of interactive decision aids. Marketing Science, 19, 4-21.

Hemingway, L. \& Priestley, M. (2006). Natural hazards, human vulnerability and disabling societies: A disaster for disabled people? Review of Disability Studies: An International Journal, 2(3), 57-67.

Hill, R. P., \& Dhanda, K. K. (1999). Gender inequity and quality of life: a macromarketing perspective. Journal of Macromarketing, 19, 140-152.

Hoffmann, F. \& Inderst, R. (2009). Price discrimination and the provision of information. Retrieved from: http://www.wiwi.uni-frankfurt.de/profs/inderst/Theory/info_price_discrimination_oct09.pdf. Accessed 8 October 2012.

Hohnen, P. (2003). A market out of place? Remaking economic, social, and symbolic boundaries in postcommunist Lithuania. Oxford: Oxford University Press.

Howells, G. (2005). The potential and limits of consumer empowerment by information. Journal of Law and Society, 32, 349-370.

Hudson, S., Snaith, T., Miller, G. A., \& Hudson, P. (2001). Distribution channels in the travel industry: Using mystery shoppers to understand the influence of travel agency recommendations. Journal of Travel Research, 40, 148-154.

Imrie, R. (2013). Designing inclusive environments and the significance of universal design. In J. Swain, S. French, C. Barnes, \& C. Thomas (Eds.), Disabling barriers-enabling environments (2nd ed.). London: Sage Publications. 
Jongman, B., Winsemius, H.C., Aerts, J.C., de Perez, E.C., van Aalst, M.K., Kron et al. (2015). Declining vulnerability to river floods and the global benefits of adaptation, Proceedings of the National Academy of Sciences of the United States of America (PNAS), 112(18), E2271-E2280.

Kaufman-Scarborough, C. (2001). Sharing the experience of mobility-disabled consumers: Building understanding through the use of ethnographic research methods. Journal of Contemporary Ethnography, 30, 430-464.

Kaufman-Scarborough, C. (2016). Social exclusion: A perspective on consumers with disabilities. In K. Hamton, S. Dunnett, \& M. Piacentini (Eds.), Consumer vulnerability: Conditions, contexts and characteristics. Oxon: Routledge.

Kaufman, C. F. (1995). Shop 'til you drop: Tales from a physically challenged shopper. The Journal of Consumer Marketing, 12, 39-55.

Kayess, R., \& French, P. (2008). Out of darkness into light? Introducing the convention on the rights of persons with disabilities. Human Rights Law Review, 8, 1-34.

Kingman, D. (2012). Spending power across the generations. London: Intergenerational Foundation.

Kivetz, R., \& Simonson, I. (2000). The effects of incomplete information on consumer choice. Journal of Marketing Research, 37, 427-448.

Lawson, A. (2010). Reasonable accommodation and accessibility obligations: Towards a more unified European approach. European Anti-Discrimination Law Review, 11, 11-21.

Lawson, A., \& Woodin, S. (2012). Maximising the impact and effectiveness of accessibility measures for goods and services: Learning from national experience. Leeds: Academin Network of European Disability experts.

Levy, B. S., \& Patz, J. A. (2015). Climate change, human rights, and social justice. Annals of Global Health, 81, 310-322.

Lietuvos Respublikos Vyriausybė (2005). No. T-5 Informacinès aplinkos pritaikymo žmoniu su negalia ugdymui metodika. Vilnius: Informacinès visuomenès plètros komiteto prie Lietuvos Respublikos Vyriausybės.

Lietuvos Statistikos Departamentas (2014). Teritorija ir gyventojų skaičius. Požymiai: administracinė teritorija, statistiniai rodikliai ir metai. Retrieved from: http://db1.stat.gov.lt/statbank/selectvarval/saveselections. asp? MainTable $=$ M3010211 $\&$ PLanguage $=0 \&$ TableStyle $=\&$ Buttons $=\&$ PXSId $=3767 \&$ IQY $=\&$ TC $=\& S T=$ ST\&rvar0=\&rvar $1=\&$ rvar2=\&rvar $3=\&$ rvar4=\&rvar5=\&rvar6=\&rvar7=\&rvar $8=\& \operatorname{rvar} 9=\& \operatorname{rvar} 10=$ \&rvar11=\&rvar12=\&rvar13=\&rvar14=. Accessed 01/07/2015.

Mégret, F. (2008). The disabilities convention: Human rights of persons with disabilities or disability rights? Human Rights Quarterly, 30, 494-516.

Miller, L. (2011). The emergence of EU contract law. Oxford: Oxford University Press.

Miller, N. J., Kim, S., \& Schofield-Tomschin, S. (1998). The effects of activity and aging on rural community living and consuming. Journal of Consumer Affairs, 32, 343-368.

Miller, R. (1998). Undercover shoppers. Marketing, 28, 1-4.

Mollan, S., \& Michie, R. (2012). The city of London as an international commercial and financial center since 1900. Enterprise and Society, 13, 538-587.

Morrall, K. (1994). Mystery shopping tests service and compliance. Bank Marketing, 26, 13-23.

Nelson, P. (1970). Information and consumer behavior. Journal of Political Economy, 78, 311-329.

Office for Disability Issues. (2010). 2012 legacy for disabled people: Inclusive and accessible business. In, Improving messages to SMEs: The case for the disabled customer. London: BISS.

Office for National Statistics. (2014). Population and migration. London: ONS.

Office of Fair Trading. (2008). Guidance on the UK regulations (May 2008) implementing the unfair commercial practices directive. Department for Business Enterprise and Regulatory Reform. OFT.

Oliver, M. (1990). The politics of disablement. New York, NY: Palgrave Macmillan.

Oliver, M. (1994). Capitalism, disability and ideology: A materialist critique of the normalization principle. Retrieved from: http://disability-studies.leeds.ac.uk/files/library/Oliver-cap-dis-ideol.pdf. Accessed 5 March 2012.

Oliver, M. (2004). The social model in action: If I had a hammer. Leeds: The Disability Press.

Oliver, M. (2009). Understanding disability. From theory to practice. New York, NY: Palgrave Macmillan.

Orru, H., Ebi, K. L., \& Forsberg, B. (2017). The interplay of climate change and air pollution on health. Current environmental health reports, 4(4), 504-513.

Otterbring, T., Wästlund, E., Gustafsson, A., \& Shams, P. (2014). Vision (im)possible? The effects of in-store signage on customers' visual attention. Journal of Retailing and Consumer Services, 21, 676-684.

Papworth Trust. (2014). Disability in the United Kingdom 2014. Cambridgeshire: Facts and figures.

Patton, M. Q. (1990). Qualitative evaluation and research methods (2nd ed.). London: Sage Publications.

Passini, R. (1996). Wayfinding design: Logic, application and some thoughts on universality. Design Studies, 17, 319-331.

Peck, J., \& Childers, T. L. (2003). To have and to hold: The influence of haptic information on product judgments. Journal of Marketing, 67, 35-48. 
Peñaloza, L. (1995). Immigrant consumers: Marketing and public policy considerations in the global economy. Journal of Public Policy and Marketing, 14, 83-94.

Peterson, R. A., \& Merino, M. C. (2003). Consumer information search behavior and the internet. Psychology and Marketing, 20, 99-121.

Prahalad, C. K., \& Ramaswamy, V. (2004). Co-creating unique value with consumers. Strategy and Leadership, 32, 4-9.

Priestley, M., Jolly, D., Pearson, C., Riddell, S., Barnes, C., \& Mercer, G. (2007). Direct payments and disabled people in the UK: Supply, demand and devolution. British Journal of Social Work, 37, 1189-1204.

Rice, P. L., \& Ezzy, D. (1999). Qualitative research methods: A health focus. Melbourne: Oxford University Press.

Ringold, D. J. (1995). Social criticisms of target marketing: Process or product? American Behavioral Scientist, $38,578-592$.

Rodgers, J. J. D. (1999). Trying to get it right: undertaking research involving people with learning difficulties. Disability \& Society, 14(4), 421-433.

Rosewarne, L. (2005). The men's gallery: Outdoor advertising and public space: gender, fear, and feminism. Women's Studies International Forum, 28, 67-78.

Rota, M., \& Schettino, F. (2011). The long-run determinants of British capital exports, 1870-1913. Financial History Review, 18, 47-69.

Ruane, J. M. (2005). Essentials of research methods. A guide to social science research. Oxford: Blackwell Publishing.

Smith, N. C., \& Cooper-Martin, E. (1997). Ethics and target marketing: The role of product harm and consumer vulnerability. Journal of Marketing, 61, 1-20.

Soghoyan, A., \& Gasparyan, K. (2017). Mental health and stigma. Global Mental Health: Springer.

Stone, E., \& Priestley, M. (1996). Parasites, pawns and partners: Disability research and the role of non-disabled researchers. The British Journal of Sociology, 47, 699-716.

Vijayasarathy, L. R., \& Jones, J. M. (2000). Print and Internet catalog shopping: Assessing attitudes and intentions. Internet Research, 10, 191-202.

VPVI. (2011). Socialinès integracijos paslaugu socialiai pažeidžiamu ir socialinès rizikos asmenu grupèms situacijos, poreikiu ir rezultatu vertinimas, siekiant efektyviai panaudoti 2007-2013m. ES strukturinę parama. Vilnius: Viešosios Politikos ir Vadybos Institutas.

Waddington, L. (2009). A disabled market: Free movement of goods and services in the EU and disability accessibility. European Law Journal, 15, 575-598.

Weatherill, S. (2011). Consumer policy. In P. Craig \& G. De Burca (Eds.), The evolution of EU law. Oxford: Oxford University Press.

Wiele, T. V. D., Hesselink, M., \& Iwaarden, J. V. (2005). Mystery shopping: A tool to develop insight into customer service provision. Total Quality Management, 16, 529-541.

Zientara, P. A., Lee, S., Smith, G. H., Brenner, R., Itti, L., Rosson, M. B., Carroll, J. M., Irick, K. M., \& Narayanan, V. (2017). Third Eye: A shopping assistant for the visually impaired. Computer, 50, 16-24.

Publisher's Note Springer Nature remains neutral with regard to jurisdictional claims in published maps and institutional affiliations. 